\title{
Complex odontomas hindering eruption of maxillary permanent teeth: a radiological perspective
}

\author{
Ankita Arora, ${ }^{1}$ Preethy Mary Donald ${ }^{2}$
}

${ }^{1}$ Department of Pedodontics, Melaka Manipal Medical College, Bukit Baru, Melaka, Malaysia

${ }^{2}$ Department of Oral Medicine and Diagnosis, Faculty of Dentistry, Melaka-Manipal Medical College, Melaka, Malaysia

\section{Correspondence to}

Dr Ankita Arora,

4ankitaarora@gmail.com

Accepted 23 July 2016
CrossMark

\begin{tabular}{l}
\hline To cite: Arora A, \\
Donald PM. BMJ Case Rep \\
Published online: [please \\
include Day Month Year] \\
doi:10.1136/bcr-2016- \\
216797
\end{tabular}

\section{DESCRIPTION}

Odontomas are benign neoplasms of odontogenic origin. They are more appropriately termed hamartomas because of their limited growth potential rather than true neoplasm. Clinically, three types of odontomas are identified in the literature: central (intraosseous) odontoma, peripheral (extraosseous or soft tissue) odontoma and erupted odontoma, whereas histologically they can be either compound (tooth-like structures) or complex (mixture of odontogenic tissues without dental organisation). ${ }^{1}$

These odontomas although benign cause disturbances in tooth eruption, such as impaction, delayed eruption or retention of primary teeth. ${ }^{2}$

\section{Case report}

A 12-year-old girl reported to the clinic for routine dental check-up. Her medical, dental and family histories were insignificant. Oral examination revealed mixed dentition with presence of overretained maxillary deciduous teeth 62,63 and 64 (FDI) in the left quadrant. An orthopantomogram was advised and it revealed unerupted permanent successors 22, 23 and 24 associated with a mixed radiopaque-radiolucent lesion. The lesion showed multiple irregular radiopaque lesions in the maxillary anterior region surrounded by a thin radiolucent rim. The calcified structures do exhibit radiodensity of tooth structures but did not show any morphological resemblance to tooth, hence diagnosed as complex odontoma radiographically (figure 1).

Odontomas blocked the path of eruption of permanent successors, hence the reason for delayed eruption of permanent lateral incisor and first premolar and impaction of canine.

The patient was referred to Department of Oral and Maxillofacial Surgery for extraction of these odontomas so that eruption of permanent successors ensues.

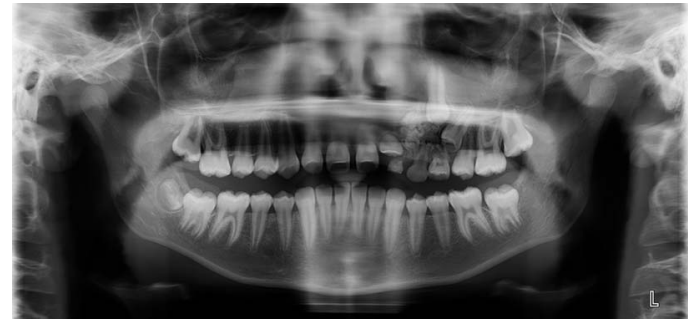

Figure 1 A dental panoramic radiograph of a 12-year-old girl showing complex odontoma hindering eruption of maxillary permanent teeth.

\section{Learning points}

- Appropriate radiographic investigations can give insight into the underlying pathology causing delayed eruption of permanent teeth.

- Extraction of odontomas, unblock the eruption pathways of permanent teeth hence, aiding in eruption and arch alignment.

\section{Competing interests None declared.}

Patient consent Obtained.

Provenance and peer review Not commissioned; externally peer reviewed.

\section{REFERENCES}

Kramer IRH, Pindborg JJ, Shear M. Histological typing of odontogenic tumours. WHO International histological classification of tumours. Berlin: Springer-Verlag. WHO, 1992.

2 Yildirim- $\mathrm{Oz}$ G, Tosun G, Kiziloglu $\mathrm{D}$, et al. An unusual association of odontomas with primary teeth. Eur J Dent 2007;1:45-9.

\footnotetext{
Copyright 2016 BMJ Publishing Group. All rights reserved. For permission to reuse any of this content visit http://group.bmi.com/group/rights-licensing/permissions.

BMJ Case Report Fellows may re-use this article for personal use and teaching without any further permission.

Become a Fellow of BMJ Case Reports today and you can:

- Submit as many cases as you like

- Enjoy fast sympathetic peer review and rapid publication of accepted articles

- Access all the published articles

- Re-use any of the published material for personal use and teaching without further permission

For information on Institutional Fellowships contact consortiasales@bmjgroup.com

Visit casereports.bmj.com for more articles like this and to become a Fellow
} 